\title{
Efforts to Overcome Truancy Behavior in Students with Biblio- Counseling (Studies in Class IX C SMP Negeri Wonomulyo)
}

\author{
Muhammad Junaedi Mahyuddin ${ }^{1}$, Fitriyanti Sulaiman², Handayani Sura ${ }^{3}$, \\ Aisyah Suryani ${ }^{4}$, Muliyadi ${ }^{5}$, M. Yasdar ${ }^{6}$, Amien Wahyudi ${ }^{7}$ \\ 1,2,3,4,5,6 Universitas Muhammadiyah Enrekang, Indonesia \\ ${ }^{7}$ Universitas Ahmad Dahlan Yogyakarta, Indonesia \\ tommuanemandar@gmail.com
}

\section{Abstract}

This research is a classroom action research (PTBK). The purpose of this study is to overcome truancy behavior of students in class IX C at SMP Negeri 1 Wonomulyo. The research subjects were taken by using a purposive sampling approaches. The number of research subjects is 8 students with truant behavior varied from 3 to 9 times. The results showed that the truant behavior of students after the first cycle of action was reduced to 0 . Thus efforts to overcome student truancy behavior can be done by using biblio-counseling.
Keywords truancy, group counseling, biblio-counseling

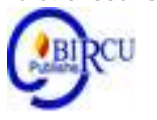

\section{Introduction}

Truancy is a form of student delinquency that needs to be addressed immediately. Truancy can be interpreted as the behavior of students who do not attend to school for inappropriate reasons (Keppens \& Spruyt, 2017; Leonard, 2017; Taylor, 2017). Another expert revealed that truancy can mean by not going to school without information, not attending school for several days, and leaving school during school hours (Kearney \& Albano, 2018; Noddings, 2017).

There are many reasons that can be explained by students related to their truancy, including low learning motivation, victims of bullying, unhappy learning or an uncomfortable learning environment (Floyd, 2017; Garner, 2019). From this point of view, it can be concluded that student truancy behavior is influenced by internal and external factors (Gottfried \& Gee, 2017; Gubbels et al., 2019; Shapira-Lishchinsky \& Raftar-Ozery, 2018). The impact of truancy causes students to experience failure in the learning process because they do not understand the subject matter in school (Baskerville, 2020; DarlingHammond et al., 2020; Donkor \& Alhassan, 2018; Ruiz et al., 2018).

Handling truancy can be done through counseling guidance services. Guidance and counseling services facilitate students to be able to solve problems that are happening in their lives (Galassi, 2017; Jones-Smith, 2020; Kok \& Low, 2017; Smith \& Wood, 2018; Sommers-Flanagan \& Sommers-Flanagan, 2018). One of the strategies that exist in guidance and counseling services is biblio-counseling or biblio-therapy (Suvilehto et al., 2019). Biblio-counseling can be done individually or in groups (İlbay, 2016; Özen \& Köksalan2i, 2019; Supriyanto \& Wahyudi, 2018; Yontz-Orlando, 2017). By implementing biblio-counseling in groups, it can provide opportunities for students to be able to express feelings, conflicts and realize joy together (Fitzgerald, 2017; MacArthur \& Mack, 2017; Tomlinson, 2018). 
Through biblio-counseling, students are given the information that needed or in accordance with the character values they want to develop. It is hoped that by knowing the information contained in readings, videos, poetry or films, students can form positive behavior. By using the biblio-counseling, teachers have many strategies to help alleviate students' problems (Bryant et al., 2019). Comics, story books, articles from newspapers or magazines, novels, or books that are classified as heavy, such as scientific writing, those things can be used to solve the problems.

To get research data and find out the root causes of truancy, researchers conducted counseling interviews. In addition, researchers also plan counseling by making intervention plans for research subjects. In group counseling, students are given the opportunity to express feelings, conflicts and show that students like to share their attention in the group. Group counseling also facilitates students to be able to discuss the impacts that arise from truancy, so that students can realize how truancy is detrimental to themselves and others.

Several studies have shown how biblio-counseling can be used to help overcome problems such as mental health, obsessive compulsive disorder, unhappiness, and increase individual motivation (Heo \& Cho, 2019; İlbay, 2016; Sevinç, 2019). Truancy behavior among junior high school students is very important to observe, because truancy behavior that occurs is a form of juvenile delinquency that can harm students, parents and schools. The behavior of students' truancy shows that students have not instilled a sense of discipline and responsibility as students.

\section{Research Methods}

This research is an action research of guidance and counseling (PTBK). Generally, the implementation of counseling guidance action research is divided into two cycles with four stages, namely: planning, implementing, observing, and reflecting.

The population of study was 20 students. From 20 students, 8 students were taken using purposive sampling. The characteristics of the students who were the research subjects were students with truant behavior varying from 3 to 9 times. The selection of research subjects was also based on the results of distributing questionnaires, observations and interviews with students and counseling teachers. The implementation of this research was designed in two cycles of activity, with the following details:

1. Cycle I was held two times

2. Cycle II was held two times

Each cycle consists of several stages of activities, namely planning, implementing, observing, and reflecting. Activities in cycle II are repetition and improvement of weaknesses in cycle I. If the first cycle has not been achieved, it will be continued in cycle II. Counseling guidance action research design which includes planning, implementation, observation, and reflection, is described as follows: 


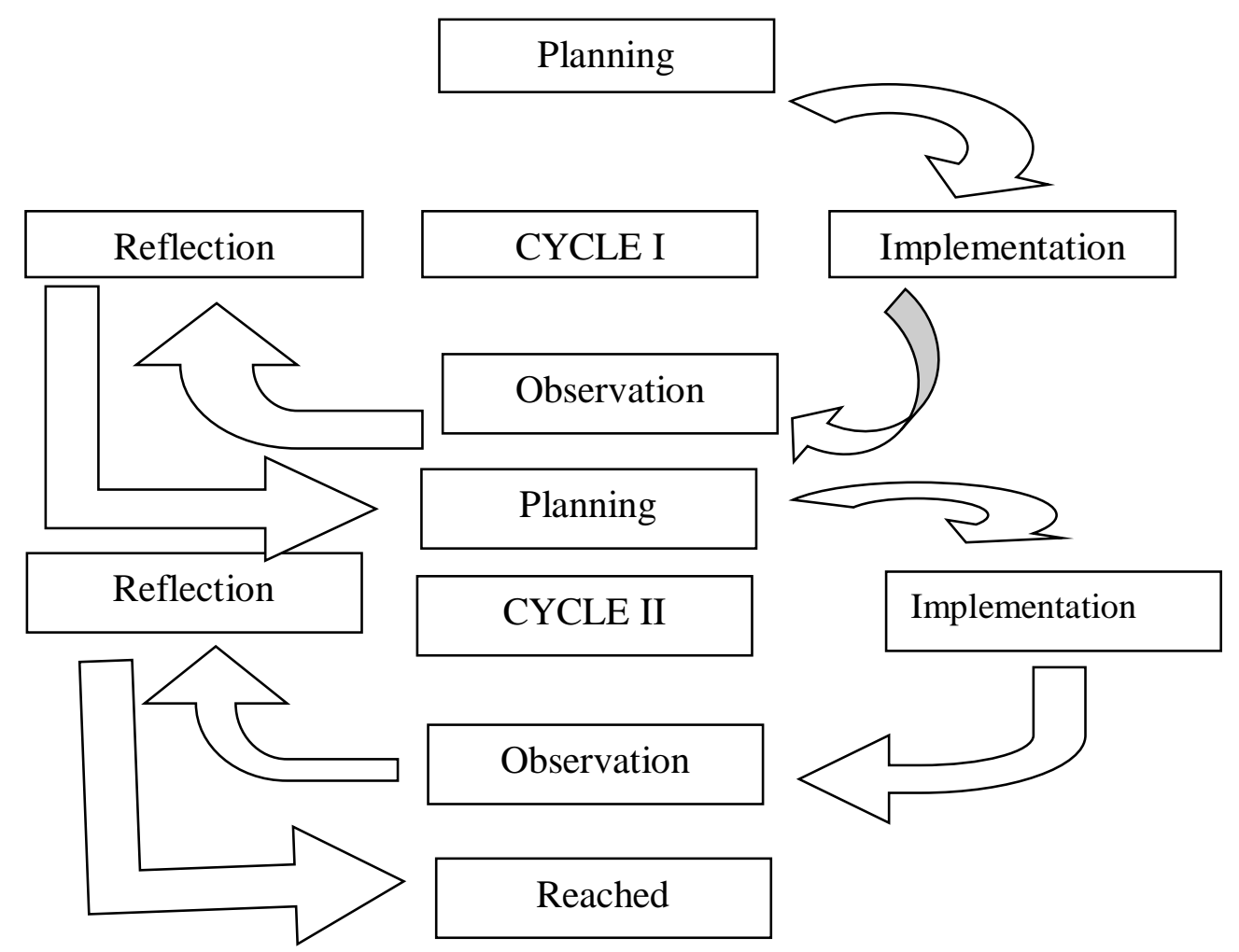

Figure 1. Research Flow According to Arikunto (2007)

\section{Results and Discussion}

The initial data used to reduce truancy behavior before the implementation of the action were the percentage of daily attendance for class IX C students in semester 2 of the $2018 / 2019$ academic year and the results of distributing questionnaires. The resulting data can be seen in the table below:

Table 1.Data of truant students for the February-April 2018 period

\begin{tabular}{|l|l|r|}
\hline NO & NAME & TRUANT \\
\hline 1 & ERM & 9 \\
\hline 2 & ATI & 0 \\
\hline 3 & HFS & 8 \\
\hline 4 & MAD & 2 \\
\hline 5 & RR & 2 \\
\hline 6 & RK & 1 \\
\hline 7 & MT & 1 \\
\hline 8 & SFR & 9 \\
\hline 9 & ATK & 7 \\
\hline 10 & IND & 1 \\
\hline 11 & ERK & 3 \\
\hline 12 & AA & 0 \\
\hline 13 & MJ & 0 \\
\hline 14 & MK & 0 \\
\hline 15 & RD & 1 \\
\hline 16 & MDH & 9 \\
\hline
\end{tabular}




\begin{tabular}{|l|l|r|}
\hline 17 & IW & 4 \\
\hline 18 & AS & 6 \\
\hline 19 & IM & 8 \\
\hline 20 & AK & 0 \\
\hline
\end{tabular}

\subsection{Percentage of Attendance and Student Questionnaire Results Post-Cycle I Action}

The percentage of the attendance and student questionnaires was carried out to determine whether there was a reduction in truancy behavior after action 1 and action 2 were carried out in cycle I. The data from this percentage helped strengthen the observation data during the action. The results of the percentage of attendance and student questionnaires are used to consider whether the next cycle needs to be implemented or not. To find out whether or not there is a reduction in truancy of students after action 1 and action 2 can be seen by comparing the total cases of truant students in semester 1 with the total cases of truant students in semester 2 after taking action. The cycle measurement used is the percentage of students' attendance in the period May-June 2018 and the results of the after-action questionnaire can be seen in the table below:

Table 2. The percentage of students' attendance in May - June 2018

\begin{tabular}{|c|c|c|c|c|c|c|}
\hline \multirow[t]{3}{*}{ No } & \multirow[t]{3}{*}{ Name } & \multicolumn{4}{|c|}{ Attendance After Cycle I Action } & \multirow[t]{3}{*}{ Total } \\
\hline & & \multicolumn{2}{|c|}{ May } & \multicolumn{2}{|c|}{ June } & \\
\hline & & $\begin{array}{l}\text { Neglect } \\
\text { (A) }\end{array}$ & $\begin{array}{c}\text { Truant } \\
\text { (B) }\end{array}$ & $\begin{array}{l}\text { Neglect } \\
\text { (A) }\end{array}$ & $\begin{array}{l}\text { Truant } \\
\text { (B) }\end{array}$ & \\
\hline 1 & ERM & 0 & 0 & 0 & 0 & 0 \\
\hline 2 & ATI & 0 & 0 & 0 & 0 & 0 \\
\hline 3 & HFS & 0 & 0 & 0 & 0 & 0 \\
\hline 4 & MAD & 0 & 0 & 0 & 0 & 0 \\
\hline 5 & RR & 0 & 0 & 0 & 0 & 0 \\
\hline 6 & RK & 0 & 0 & 0 & 0 & 0 \\
\hline 7 & MT & 0 & 0 & 0 & 1 & 1 \\
\hline 8 & SFR & 0 & 0 & 0 & 0 & 0 \\
\hline 9 & ATK & 0 & 0 & 0 & 0 & 0 \\
\hline 10 & IND & 0 & 0 & 0 & 0 & 0 \\
\hline 11 & ERK & 0 & 0 & 0 & 0 & 0 \\
\hline 12 & AA & 0 & 0 & 0 & 0 & 0 \\
\hline 13 & MJ & 0 & 0 & 0 & 0 & 0 \\
\hline 14 & MK & 0 & 0 & 0 & 0 & 0 \\
\hline 15 & RD & 0 & 0 & 0 & 0 & 0 \\
\hline 16 & $\mathrm{MDH}$ & 0 & 0 & 0 & 0 & 0 \\
\hline 17 & IW & 0 & 0 & 0 & 0 & 0 \\
\hline 18 & AS & 0 & 0 & 0 & 0 & 0 \\
\hline 19 & IM & 0 & 0 & 0 & 0 & 0 \\
\hline 20 & AK & 0 & 0 & 0 & 0 & 0 \\
\hline
\end{tabular}

From table 2 above, it is known that from the 8 research subjects, there were already 7 students who skipped class which had reduced to 0 , and 1 student was still found to be truant 1 time. But if we look at the comparison of truancy behavior between February and May, it can be concluded that the overall truancy behavior of students has decreased. 
Based on interviews with students, it is known that group counseling with bibliocounseling techniques is a fun activity, because students get a lot of information and can express their opinions freely. In addition, students also feel motivated to leave the habit of truancy because students do not want to stay in class. However, when the researcher asked about the habit of being late and permission to leave the class, some students answered that the students did not skip school because the students continued to enter class and had been absent by the subject teacher. There are several shortcomings and obstacles that were found from the reflection of cycle I, that are:

1. During the implementation of group counseling, there were disturbances from outside of the classroom and there were still students talking to themselves but this can be overcome by the counseling teacher by dividing groups and explaining that the activity to be carried out was reading books.

2. During the presentation, question and answer between groups there were obstacles where some students took verbal aggressive actions against their friends by making them bad examples of the presentation material, but the noise did not last longer and the activity could be well-continued.

3. The group counseling discussion process runs in an orderly manner, students are enthusiastic about following the course of action, although not all students can convey their opinions well. After the action, there has also been a change in attitude shown by the students.

The results of the evaluation of the II cycle 1 actions that were carried out showed that: there were changes from the students before the action and after the first cycle action done. Efforts to reduce student truancy through biblio-counseling in group counseling have also gone according to plan. The reduction of truancy behavior can be seen from the preaction student attendance data and the post-action student percentage data.

Table 3. Comparison of truancy behavior before and after the action.

\begin{tabular}{|l|l|l|l|l|l|}
\hline \multirow{2}{*}{ No } & \multirow{2}{*}{ Name } & Pre-Action & \multirow{2}{*}{ Total } & Post- Action & \multirow{2}{*}{ Total } \\
\cline { 3 - 5 } & & Truant & & Truant & \\
\hline 1 & ERM & 9 & 9 & 0 & 0 \\
\hline 2 & ATI & 0 & 0 & 0 & 0 \\
\hline 3 & HFS & 8 & 8 & 0 & 0 \\
\hline 4 & MAD & 2 & 2 & 0 & 0 \\
\hline 5 & RR & 2 & 2 & 0 & 0 \\
\hline 6 & RK & 1 & 1 & 0 & 0 \\
\hline 7 & MT & 0 & 0 & 0 & 0 \\
\hline 8 & SFR & 9 & 9 & 0 & 0 \\
\hline 9 & ATK & 7 & 7 & 0 & 0 \\
\hline 10 & IND & 1 & 1 & 0 & 0 \\
\hline 11 & ERK & 3 & 3 & 0 & 0 \\
\hline 12 & AA & 0 & 0 & 0 & 0 \\
\hline 13 & MJ & 0 & 0 & 0 & 0 \\
\hline 14 & MK & 0 & 0 & 0 & 0 \\
\hline 15 & RD & 0 & 0 & 0 & 0 \\
\hline 16 & MDH & 9 & 9 & 0 & 0 \\
\hline 17 & IW & 4 & 4 & 0 & 0 \\
\hline 18 & AS & 6 & 6 & 0 & 0 \\
\hline 19 & IM & 8 & 8 & 0 & 0 \\
\hline 20 & AK & 0 & 0 & 0 & 0 \\
\hline
\end{tabular}


When viewed in a picture, the results of the comparison of the results before the action and after the action are as shown below:

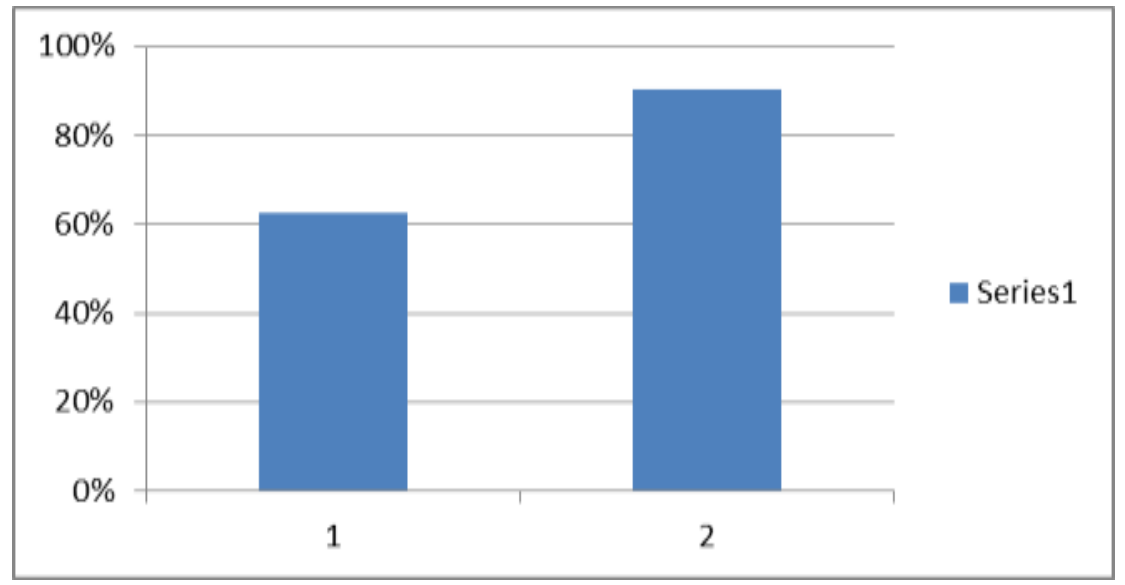

Figure 2. Comparison of results before action and after action

The image above shows that overall truancy has decreased. When viewed from the category, truancy behavior in category A has reduced its frequency to 0 where previously the frequency range ranged from 1 to 4 times. Then truancy in category B there were 4 children whose truant behavior was in the range 1 to 2 which occurred in April. However, if we look at the recapitulation at the presentation in May, both category A and category B truancy behavior of all students have decreased to 0 .

Besides truancy behavior, other data shows that student tardiness has also decreased. If there are still students who are late, usually during the first lesson and after the break, this can still be tolerated by the subject teacher. The results obtained in this study have gone according to plan and in accordance with the criteria set by the researcher. The implementation of the action also went very well, there were no significant obstacles during the research and the results achieved were good, so the researcher decided not to continue to the next cycle.

\subsection{Discussion}

This study used biblio-counseling as an effort to help students reduce truancy. Truancy is associated with maladaptive behavior such as bullying and ignorance (Iverson et al., 2018; Smalley et al., 2017; Taylor, 2017). Other studies have also shown a relationship between truancy behaviors caused by deprivation during school (Spruyt et al., 2017). Truancy is also associated with criminal acts committed by individuals and related to a person's economic condition (Robinson, 2020; Virtanen et al., 2020).

Biblio-counseling is an individual thought intervention activity by using reading materials so that after reading the individual gets new information and can apply it in everyday life (Ilogho et al., 2020; Ogbeide \& Adomeh, 2019; Shem, 2016). Implementation of biblio-counseling is one way in the practice of group counseling services. Group counseling is the implementation of a dynamic interpersonal process, focused on conscious thought and behavior, and involves therapeutic functions, such as permissiveness, orientation to reality, mutual trust, mutual understanding, mutual acceptance and support (Briesch Du Bois et al., 2017; Levy, 2018; Lewis, 2019; Nunez et al., 2018).

Based on the results of observations, it is known that the number of truantcy behavior by individuals is reduced. Students are diligent in going to school and following class 
hours to completion, the negative habits of students who often leave the classroom are no longer done, so that students do not miss the important subject were given. Then when participating in the lessons students also appear more active, this can be seen when students ask questions to the teacher. Improvements in behavior and attitudes cannot be separated from the counseling process, because group counseling can help individuals achieve optimal development (Anastasov \& Ristevska, 2019; Galassi, 2017; Hamm et al., 2016).

Based on the results of interviews with students related to Biblio-counseling techniques in group counseling, students were able to conclude the negative effects of truancy and reflect on the experiences that students had so far. This success is because students reflect on what will happen in the future if students continue their truancy behavior and students decide to stop truancy after students realize the long-term impact of truancy behavior.

In addition, students are also motivated to prepare themselves after graduating from junior high school (SMP) to continue to the senior high school (SMA/SMK) level. The results of this study are in accordance with the research objectives, which can reduce truancy behavior of students. This research also adds to the scientific knowledge about reducing truancy behavior by using Biblio-counseling.

\section{Conclusion}

The given of biblio-counseling techniques in group counseling can overcome truancy behavior of students in class VIIIC at SMP Negeri 1 Wonomulyo. This can be seen from the data on student attendance percentage in the second semester of 2017/2018 for the period of February - April, where truancy behavior starting from pre-action, post-action I cycle I, and post-action II has decreased significantly.

Pre-action truancy behavior data ranged from 3 to 9 . Then the truancy behavior data after the first cycle of truancy behavior has decreased where 8 children with truant behavior have reached the number 0 . Thus the final results of this study all students who are the subject of truancy behavior research have reduced to 0 .

Based on the conclusions above, it is suggested that the counseling teacher can use biblio-counseling techniques in group counseling to overcome truancy behavior of students. We hope students who stopped the truancy behavior can be maintained and optimize learning activities so that the desired goals can be achieved.

\section{References}

Anastasov, B., \& Ristevska, M. (2019).The Role Of The Counselor In The Pedagogical Counseling Process. International Journal of Education TEACHER, 9(18), 54-59.

Arikunto, Suharismi Dkk. 2007. Penelitian Tindakan Kelas, Bumi Askara,

Jakarta

Baskerville, D. (2020). Mattering; changing the narrative in secondary schools for youth who truant. Journal of Youth Studies, 1-16.

Briesch DuBois, J. M., Briesch, A. M., Hoffman, J. A., Struzziero, J., \& Toback, R. (2017). Implementing self-management within a group counseling context: Effects on academic enabling behaviors. Psychology in the Schools, 54(8), 852-867.

Bryant, D. P., Bryant, B. R., \& Smith, D. D. (2019). Teaching students with special needs in inclusive classrooms. Sage Publications. 
Darling-Hammond, L., Flook, L., Cook-Harvey, C., Barron, B., \& Osher, D. (2020). Implications for educational practice of the science of learning and development. Applied Developmental Science, 24(2), 97-140.

Donkor, A. K., \& Alhassan, A. (2018). Training teachers to manage truancy at Savelugu West Circuit of education in Northern Ghana.

Fitzgerald, J. P. (2017). Developing a Strategy for Biblical Counseling Socially Dysfunctional People [PhD Thesis]. Southeastern Baptist Theological Seminary.

Floyd, M. (2017). How did you get here? Where are you going?: an exploration of the school experiences of high school students from a high poverty background. $[\mathrm{PhD}$ Thesis].

Galassi, J. (2017). Strengths-based school counseling: Promoting student development and achievement. Routledge.

Garner, S. (2019). Mental Health in Education: Building Good Foundations. Routledge.

Gottfried, M. A., \& Gee, K. A. (2017). Identifying the determinants of chronic absenteeism: A bioecological systems approach. Teachers College Record, 119(7), $1-34$.

Gubbels, J., van der Put, C. E., \& Assink, M. (2019). Risk factors for school absenteeism and dropout: A meta-analytic review. Journal of Youth and Adolescence, 48(9), 1637-1667.

Hamm, J. S., Carlson, J., \& Erguner-Tekinalp, B. (2016). Adlerian-based positive group counseling interventions with emotionally troubled youth. The Journal of Individual Psychology, 72(4), 254-272.

İlbay, A. B. (2016). The impact of biblio group counseling supported with the story of the little prince upon mindfulness. Journal of Education and Training Studies, 4(6), 5868.

Ilogho, J. E., Alao, A., Adekeye, O., Gesinde, A., Adeusi, S., \& Ifijeh, G. (2020). The prevalence of bibliotherapy program practice among helping professionals in Ota, Nigeria: A pilot study. Journal of Poetry Therapy, 33(1), 30-43.

Iverson, A., French, B. F., Strand, P. S., Gotch, C. M., \& McCurley, C. (2018). Understanding school truancy: Risk-need latent profiles of adolescents. Assessment, 25(8), 978-987.

Jones-Smith, E. (2020). Theories of counseling and psychotherapy: An integrative approach. SAGE Publications, Incorporated.

Kearney, C. A., \& Albano, A. M. (2018). When children refuse school: Therapist guide. Oxford University Press.

Keppens, G., \& Spruyt, B. (2017). The development of persistent truant behaviour: An exploratory analysis of adolescents' perspectives. Educational Research, 59(3), 353370.

Kok, J. K., \& Low, S. K. (2017). Proposing a collaborative approach for school counseling. International Journal of School \& Educational Psychology, 5(4), 281289.

Leonard, L. (2017). Level of Appreciation, Self Concept and Positive Thinking on Mathematics Learning Achievement.Jurnal Lppm Unindra.

Levy, I. P. (2018). Aligning Community Defined Practice with Evidence Based Group Counseling: The Hip-hop Cypher as Group Counseling. In \# HipHopEd: The Compilation on Hip-hop Education (pp. 170-157). Brill Sense.

Lewis, J. (2019). Does Emotional Intelligence Moderate the Effect of Field Work Experience on Counseling Students' Group Counseling Self-Efficacy. 
MacArthur, J. F., \& Mack, W. A. (2017). Counseling: How to Counsel Biblically. Thomas Nelson.

Noddings, N. (2017). When school reform goes wrong. Teachers College Press.

Nunez, B., Motheral, L., Pomeroy, L., Camp, T., \& Johnson, L. (2018). Improving Pediatric Resident Wellness through Group Counseling Sessions. Am Acad Pediatrics.

Ogbeide, C., \& Adomeh, I. O. (2019). Effectiveness of bibliotherapy in enhancing learning among secondary school students in Nigeria. Journal of Education and Entrepreneurship, 6(1), 19-28.

Özen, Y., \& Köksalan2i, B. (2019). A New Way of Learning And Well Being:Bibliotherapy. European Journal of Education Studies, 5(10), 119.

Robinson, J. (2020). The Relationship Between Student Basic Psycological Needs Satifaction And Truancy. https://hdl.handle.net/11244/323821. OU - Dissertations

Ruiz, I., Mink, J., \& Aleman, X. (2018). Truancy in High School. SPACE: Student Perspectives About Civic Engagement, 3(1), 3.

Shapira-Lishchinsky, O., \& Raftar-Ozery, T. (2018). Leadership, absenteeism acceptance, and ethical climate as predictors of teachers' absence and citizenship behaviors. Educational Management Administration \& Leadership, 46(3), 491-510.

Shem, M. (2016). Bibliotherapy as a Problem-Solving Skill of Counsellors and Teachers for Character and Skills Development in Ogun State, Nigeria. Journal of Education and Practice, 7(20), 18-22.

Smalley, K. B., Warren, J. C., \& Barefoot, K. N. (2017). Connection between experiences of bullying and risky behaviors in middle and high school students. School Mental Health, 9(1), 87-96.

Smith, C. K., \& Wood, S. M. (2018). Career counseling for the gifted and talented: A life span development approach. In Handbook of Giftedness in Children (pp. 315-333). Springer.

Sommers-Flanagan, J., \& Sommers-Flanagan, R. (2018). Counseling and psychotherapy theories in context and practice: Skills, strategies, and techniques. John Wiley \& Sons.

Spruyt, B., Keppens, G., Kemper, R., \& Bradt, L. (2017). 'If only they had a file on every pupil': On the mismatch between truancy policy and practice in Flanders. International Studies in Sociology of Education, 26(2), 171-189.

Supriyanto, A., \& Wahyudi, A. (2018). Group Guidance Services Based on Folklore for Students Junior High School. International Journal of Indonesian Education and Teaching (IJIET), 2(1), 37-46.

Suvilehto, P., Kerry-Moran, K. J., \& Aerila, J.-A. (2019). Supporting children's social and emotional growth through developmental bibliotherapy. In Story in Children's Lives: Contributions of the Narrative Mode to Early Childhood Development, Literacy, and Learning (pp. 299-314). Springer.

Taylor, M. B. (2017). Student Perceptions of Influences on Truant Behavior in a Western Pennsylvania School: A Qualitative Case Study [PhD Thesis]. Northcentral University.

Tomlinson, J. N. (2018). Equipping Small Group Leaders To Understand And Practice The Ministry Of Biblical Counseling At Coastal Community Church, Yorktown, Virginia.

Virtanen, T. E., Räikkönen, E., Lerkkanen, M.-K., Määttä, S., \& Vasalampi, K. (2020). Development of Participation in and Identification With School: Associations With Truancy. Journal of Early Adolescence.

Yontz-Orlando, J. (2017). Bibliotherapy for mental Health. International Research in Higher Education, 2(2), 67-73. 